Chirurgia (2021) 116: 664-668

No. 6, November - December

Copyright@ Celsius

http://dx.doi.org/10.21614/chirurgia.116.6.664

\title{
Polytrauma: The European Paradigm
}

\author{
Claudiu Ștefan Turculeț, ${ }^{1,2}$, Teodor Florin Georgescu ${ }^{1,2 \star}$, Florin Iordache ${ }^{1,2}$, Dragoș Ene ${ }^{1,2}$, Bogdan Gașpar ${ }^{1,2}$, \\ Mircea Beuran ${ }^{1,2}$
}

1Department of General Surgery, Clinical Emergency Hospital, Bucharest, Romania

2"Carol Davila" University of Medicine and Pharmacy, Bucharest, Romania

${ }^{*}$ Corresponding author:

Teodor Florin Georgescu, MD, PhD

Department of General Surgery

Clinical Emergency Hospital

8 Calea Floreasca, 014461

Bucharest, Romania

E-mail: florin.georgescu1@yahoo.com

\section{Rezumat}

Politrauma: Paradigma Europeană

Această revizuire a literaturii are ca scop descrierea principalelor avantaje şi dezavantaje ale sistemelor de traumă din Europa. Totodată, lucrarea îşi propune să prezinte ultimele concepte în ceea ce priveşte managementul pacienților politraumatizați şi cele mai noi măsuri pentru prevenirea accidentelor rutiere în Uniunea Europeană. Articolele publicate referitoare la managementul pacienților politraumatizați şi la organizarea sistemelor de traumă au fost identificate prin căutarea în baza de date PubMed. Managementul optimal al politraumatismelor majore necesită un sistem național de traumă ce trebuie să ia in considerare toate nivelurile de organizare de la centrele de traumă ce deservesc o arie importanta geografică, până la membrul fiecărei echipe de traumă. Sistemele de traumă din Europa suferă variații mari în funcție de țară, iar specializarea chirurgului de traumă este mai avansată în țările cu sisteme de traumă dezvoltate. Introducerea unor indicatori de siguranță rutieră pentru managementul politraumatismelor a scăzut rata deceselor cauzată de accidente rutiere în Europa.

Cuvinte cheie: politraumatism, accident rutier, sistem de traumă

\section{Abstract}

This review of the literature aims to describe the main advantages and disadvantages of the trauma systems in Europe. Moreover, the purpose of this article is to present the last concepts regarding the 
management of the polytrauma patients and the newest sets of measures to prevent car crashes in European Union. The articles published regarding the management of the polytrauma patient and trauma systems were identified using PubMed search. Optimal management of major polytrauma requires a national trauma system which should detail every level of organization from the trauma centers to the every member of the trauma team. European trauma systems varies a lot depending on the country and the specialized trauma surgery training programs are more advanced in countries with complex trauma systems. Introducing road safety performance indicators for trauma management decreased the rate of deaths by car crashes in Europe

Key words: polytrauma, car crash, trauma system

\section{Introduction}

Trauma represents the most important factor related to death for patients below 45 years old in industrialized countries $(1,2)$. In Europe, a significant percentage of all polytrauma is represented by car crashes. The number of deceased patients due to car crashes continues to rise. According to World Health Organization, the number of persons who died in car accidents was 1.35 million in 2016 (3). In Europe, between 2001 and 2010 the number of deaths produced by car crashes decreased with 43\%, and between 2010 and 2018 with another 21\%. Still, 25100 persons lost their life on the roads of the European Union in 2018 and approximately 135000 were severely injured (4). The annual cost with car accidents in the European Union was estimated to approximately 280 billion euro, the equivalent of $2 \%$ of the Gross Domestic Product (GDP) (5).

The notion of polytrauma was first used in 1966 by Tscherne for patients who presented at least 2 severe injuries of the abdomen, chest or head, or one of these lesions in combination with an extremity injury. In 1975, Border summarized the term polytrauma to a patient with two or more significant injuries. Then, Ostern updated the concept of polytauma to a patient with two or more lesions, one of them being life threatening (6-8). In Romania, there has been a constant interest in polytauma patients. The first chapter about polytrauma was written in 1975, then other authors published the latest updates regarding the concepts and management of polytraumatized patients $(9-12)$.

In the last years a new definition of polytrauma was designed. The new Berlin definition of polytrauma included: a patient with AIS $\geq 3$ for two or more different body regions and with one or more additional parameters from the following:

- Glasgow comma scale (GCS) $\leq 8$;

- Systolic blood pressure $(\mathrm{SBP}) \leq 90$ $\mathrm{mmHg}$;

- Partial thromboplastin time $\geq 40$ seconds or international normalized ratio $\geq 1.4$;

- Age $\geq 70$ years (13).

After comparing this new definition of polytrauma with ISS alone, a group of researchers concluded that the Berlin definition adds value to the individual rating of the polytrauma patients. Moreover, the study revealed that the new definition of polytrauma can improve the activity of the trauma centers (14).

A new concept in polytrauma patients is represented by resuscitation associated coagulopathy. This phenomenon occurs when the patients develop coagulopathy due to aggressive volume infusions. This new concept is different than the acute traumatic coagulopathy which is produced by the lethal triad that appears in severe polytrauma patients (acidosis, hypothermia and coagulopathy) (15). The damage control resuscitation was updated which balances the administration of plasma, platelets and red blood cells (1:1:1) and the results showed an improved survival 
of these patients in the first day $(16,17)$. Borderline polytrauma patients are those who are initially stabilized, but are still at risk of rapid deterioration due to different risk factors. Some of these risk factors include: coagulopathy (ROTEM/FIBTEM), massive transfusion (more than 10 units of red blood cells per 6 hours) or more 3 units of red blood cells per hour (18).

Another new treatment concept of the polytrauma patient is the neutrophil guided resuscitation. Depending on the neutrophil phenotype, treatment of these patients can be modified and prognosis better approximated. CD16 and CD 62L are the markers used for neutrophil differentiation. Polytrauma patients have up to $22 \% \mathrm{CD} 16 \mathrm{dim} / \mathrm{CD} 62 \mathrm{~L}$ bright neutrophils, but further studies should be conducted to accumulate more data (19).

An important change in the management of polytrauma patients was the introduction of non-operative treatment. One important tool required for the success of the non-operative treatment is the possibility to perform an angiography and control the bleeding by embolization abdominal and pelvic vessels (20). The non-operative treatment should be considered only in trauma centers by experienced trauma surgeons (21).

Trauma systems developed as organized mechanisms to offer the best treatment for trauma patients from pre-hospital care to complete rehabilitation, aiming the best outcome possible (22). The first regional trauma system was introduced in Illinois in 1971. In Europe, the first countries which implemented organized approaches to trauma patients were Germany, Austria and Switzerland by developing helicopter air rescue programs and training of general surgeon-traumatologists (23). The Dutch trauma system and the nationwide trauma registry were introduced in 1999. The registry included all trauma patients admitted in Netherlands. Even though in other countries such as the USA and the Scandinavian countries, the accent is put on the lethal truncal lesions, in Netherlands the trauma surgeons treat both visceral and extremity injuries (24). The training of a trauma surgeon in Netherlands includes 4 years training in general surgery and another two years in trauma surgery, which includes courses in ATLS (advanced trauma life support), resuscitation, fracture and visceral surgical interventions. In the level 1 centers the Dutch surgeon is actively treating polytrauma patients in the intensive care unit $(25,26)$. The Dutch trauma system includes 11 trauma regions and has 3 levels trauma centers. The introduction of the trauma system alongside with the national registry had a positive effect like in most other countries who implemented similar systems (27). Beside the logistical improvement, there was a change in the management of polytraumatized patients, non-operative treatment and damage control principles being more used in the resuscitation process and also in the treatment of fractures related lesions $(28,29)$. In Netherlands, the crude mortality of polytraumatized patients decreased with $50 \%$ after the implementation of trauma system. Furthermore, over the past 20 years the mortality adjusted for Injury Severity Score (ISS) and age registered $75 \%$ reduction in the level 1 trauma centers in Netherlands (30). In Spain, the trauma system focused on the optimization of medical assistance across all stages of trauma care, continuous registration of all trauma patients, permanent training in Advanced Trauma Life Support and in the pathology most encountered in polytraumatized patients, continuously revising and updating trauma guidelines, classification of the hospitals in accordance with the resources available to treat trauma patients, accreditation of medical professionals depending on their experience and skills to treat trauma patients, improving rehabilitation assistance, encouraging research and the collaboration of scientific societies with community administration to ensure a better primary prevention of accidents (31). In Romania, a national trauma registry was designed several years ago by the General Surgery Department of the Clinical Emergency Hospital Bucharest and given to the Health Ministry, but due to lack of funds it was not implemented. 
An important aspect in the evolution of polytraumatized patients is the cause of death. If in the past, the main cause of death for these patients was the multiple organ dysfunction syndrome (MODS), in the last years brain injury became the leading cause of death. Another change observed was the increasing bleeding-related deaths in the Intensive Care Units (ICU) in the last period of time (32). Other studies showed that the hemorrhage-related deaths decreased with almost $20 \%$ in the last 20 years due to improvement of the management of the polytraumatized patients from pre-hospital to ICU. Also, it was documented that because of the implementation of ATLS, the mortality within one hour after admission decreased. The introduction of damage control principles and the possibility to perform computer tomography obtaining a rapid diagnosis reduced further the mortality after admission of the polytraumatized patients (33-35).

Car accidents represent the leading cause of death for young patients between 15 and 29 years. Even though it is registered a considerable decrease of road traffic fatalities, especially in Europe, active measures should be taken to sustain and improve this current trend. Unfortunately, Romania occupies a top position in the European Union car accidents ranking (36).

The European Union elaborated a set of themes to improve road safety for traffic participants:

- infrastructure - safety roads and road verges - measured by the traveled distance with no accidents;

- safe vehicles - measured by the percentage of all new vehicles with an established safety threshold;

- use of roads in safety conditions:

- safety speed - measured by the percentage of cars which respect the speed limits;

- lucid driver (no alcohol or drug consumption) - percentage of drivers who respect the law;

- preventing distraction when driving measured by the percentage of drivers who doesn't use a cell phone when driving;

- using safety seat belts, safety systems and protection equipment - percentage of traffic participants who respect the recommendations;

- encouraging other ways to travel - bicycle, public transport;

- safety measures at work for transporters;

- rapid and efficient interventions in emergency situations refers to efficient care after the accident - indicator measured by the time between the emergency call and the arrival of medical services at the site of the accident (37).

The World Health Organization (WHO) underlines the importance of the following disciplines in decreasing the number of casualties caused by car accidents: sociology, statistics, engineering, psychology, law, policing, bio-mechanics, policy analysis, pharmacology, emergency medicine, surgery and rehabilitation medicine. WHO encourages countries to develop their own safety strategies regarding road traffic, in order to lower traffic injuries and make safer roads (38). To achieve these objectives, every country should start their strategy with epidemiological studies, which are very useful to obtain the data needed for implementing targeted measures on traffic injury prevention and control (39).

\section{Conclusion}

In conclusion, in order to lower the incidence and to improve the outcome of polytraumatized patients, every healthcare system should focus on taking measures to prevent accidents which can produce casualties, to implement a national trauma system and registry, and to continuously train trauma specialists because being updated with all the current concepts and treatments is crucial for obtaining better results in this complex pathology.

\section{Conflicts of Interest}

The authors declare no conflicts of interests. 


\section{References}

1. Bardenheuer M, Obertacke U, Waydhas C, Nast-Kolb D. Epidemiology of severe multiple trauma. A prospective assessment of preclinical and clinical management. Unfallchirurg. 2000;103(5):355-63. German

2. Vyrostek SB, Annest JL, Ryan GW. Surveillance for fatal and nonfatal injuries in the United States - 2001. MMWR CDC Surveill Summ 2004;53:1-57

3. https://eur-lex.europa.eu/legal-content/R0/TXT/ ?qid=1566377309148\&uri $=$ CELEX:52018DC0293

4. http://europa.eu/rapid/press-release_IP-19-1951_en.htm

5. https://ec.europa.eu/transport/themes/sustainable/studies/sustainable_en

6. Tscherne H. The Treatment of the Seriously Injured at an Emergency Ward Chirurg. 1966;37(6):249e252

7. Border JR, LaDuca J, Seibel R. Priorities in the management of the patien with polytrauma. Prog Surg. 1975;14:84-120.

8. Oestern HJ, Regel G. Klinische Behandlung des Schwerverletzten. In: Tscherne H, Unfallchirurgie Regel G, eds. Trauma Manamement. Chapter 9 Berlin, Heidelber, New York: Springer; 1997:225-238

9. Suteu I, Troianescu 0, Briciu R, Bucur A, Chinta Gh, Ciurel M, et al Îndreptar de Urgente Traumatologice - „Politraumatisme” - C. Petrescu. Bucuresti: Ed. Medicală; 1975

10. Niculescu Gh. Politraumatismele membrelor în condiții catastrofale după experienta marelui cutremur din 1977. Presa si publicatiile Ministerului Apărării Naționale, București, 1982.

11. Ionescu Gh, Turculet C. În: N. Angelescu editor. Tratat de patologie chirurgicală, Politraumatismele, vol. I. București: Ed. Medicală; 2001.

12. Turculet C, Georgescu TF, Valcu P, Beuran M. În: Patrascu T, Beuran M, coordonatori. Manual de chirurgie pentru rezidenți, Vol. II, Capitolul 24.1 „Politraumatismele”, Capitolul 24.2 - „Traumatismele abdominale”. Bucuresti: Editura Universitara „Carol Davila”; 2021, pag. 263 - 285, pag. $286-306$

13. Pape HC, Lefering R, Butcher N, Peitzman A, Leenen L, Marzi I, et al. The definition of polytrauma revisited: An international consensus process and proposal of the new 'Berlin definition'. J. Trauma Acute Care Surg. 2014;77: 780-786.

14. Pothmann CEM, Baumann S, Jensen KO, Mica L, Osterhoff G, Simmen HP, et al. Assessment of polytraumatized patients according to the Berlin Definition: does the addition of physiological data really improve interobserver reliability? PLoS One. 2018;13(8):e0201818.

15. Hess JR, Brohi K, Dutton RP, Hauser CJ, Holcomb JB, Kluger Y, et al. The coagulopathy of trauma: a review ofmechanisms. J Trauma. 2008; 65(4):748-54.

16. Baraniuk S, Tilley BC, del Junco DJ, Fox EE, van Belle G, Wade CE, et al Pragmatic randomized optimal platelet and plasma ratios (PROPPR) trial: design, rationale and implementation. Injury. 2014:45(9):1287-95.

17. Holcomb JB, Tilley BC, Baraniuk S, Fox EE, Wade CE, Podbielski JM, et al. Transfusion of plasma, platelets, and red blood cells in a 1:1:1 vs a 1:1:2 ratio and mortality in patients with severe trauma the PROPPR randomized clinical trial. JAMA. 2015;313(5):471-82.

18. Pape HC, Halvachizadeh S, Leenen L, Velmahos GD, Buckley R, Giannoudis PV. Timing of major fracture care in polytrauma patients - an update on principles, parameters and strategies for 2020. Injury. 2019;50(10):16561670.

19. Spijkerman R, Hesselink L, Bongers S, van Wessem KJP, Vrisekoop N,
Hietbrink $F$, et al. Point-of-care analysis of neutrophil phenotypes: a first step towards immuno-based precision medicine in the trauma ICU. Crit Care Explor. 2020;2(7):e0158

20. Petrone P, Anduaga Peña MF, Servide Staffolani MJ, Brathwaite C, Axelrad A, Ceballos Esparragón J. (2017) Evolution of the treatment of splenic injuries: from surgery to non-operative management. Cir Esp. 2017; 95(8):420-427. English, Spanish

21. Howes N, Walker T, Allorto NL, Oosthuizen GV, Clarke DL. Laparotomy for blunt abdominal trauma in a civilian trauma service. S Afr J Surg. 2012; 50(2):30-2.

22. Hoff WS, Schwab CW. Trauma system development in North America. Clin Orthop Relat Res. 2004;(422):17-22

23. Allgöwer M. Trauma systems in Europe. Am J Surg. 1991:161(2):226-9.

24. Ciesla DJ, Moore EE, Cothren CC, Johnson JL, Burch JM. Has the trauma surgeon become house staff for the surgical subspecialist? Am J Surg. 2006;192(6):732-7.

25. Goslings JC, Ponsen KJ, Luitse JS, Jurkovich GJ. Trauma surgery in the era of nonoperative management: the Dutch model. J Trauma. 2006;61(1):111-4;

26. Sturm JA, Pape HC, Dienstknecht T. Trauma care in Germany: aninclusive system. Clin Orthop Relat Res. 2013;471(9):2912-23.

27. Moore L, Champion H, Tardif PA, Kuimi BL, O'Reilly G, Leppaniemi A, et al. Impact of trauma system structure on injury outcomes: a systematic review and meta-analysis. World J Surg. 2018;42(5):1327-1339.

28. Waibel BH, Rotondo MM. Damage control surgery: it's evolution over the last 20 years. Rev Col Bras Cir. 2012;39(4):314-21.

29. Poortman P. Meeuwis JD, Leenen LP. Multitrauma patients: principles of 'damage control surgery'. Ned Tijdschr Geneeskd. 2000;144(28):1337-41. Dutch

30. Hietbrink F, Houwert RM, van Wessem KJP, Simmermacher RKJ, Govaert GAM, de Jong MB, et al. The evolution of trauma care in the Netherlands over 20 years. Eur J Trauma Emerg Surg. 2020:46(2):329-335.

31. Queipo de Llano E, Mantero Ruiz A, Sanchez Vicioso P, Bosca Crespo A, Carpintero Avellaneda JL, de la Torre Prado MV. Trauma care systems in Spain. Injury. 2003;34(9):709-19

32. van Breugel JMM, Niemeyer MJS, Houwert RM, Groenwold RHH, Leenen LPH, van Wessem KJP. Global changes in mortality rates in polytrauma patients admitted to the ICU-a systematic review. World J Emerg Surg. 2020;15(1):55.

33. Pfeifer R, Tarkin IS, Rocos B, Pape HC. Patterns of mortality and causes of death in polytrauma patients-has anything changed? Injury. 2009;40(9): 907-11.

34. van Olden GD, Meeuwis JD, Bolhuis HW, Boxma H, Goris RJA. Advanced trauma life support study: quality of diagnostic and therapeutic procedures. J Trauma. 2004:57(2):381-4.

35. Browne J, Coats TJ, Lloyd DA, Oakley PA, Pigott T, Willett KJ, et al. High quality acute care for the severely injured is not consistently available in England, Wales and Northern Ireland: report of a survey by the Trauma Committee, The Royal College of Surgeons of England. Ann R Coll Surg Engl. 2006:88(2):103-7.

36. World HealtH organization. Global status report on road safety 2013.

37. Cadrul de politică al UE privind siguranta rutieră 2021-2030 - Următorii pasi în directia "Viziunii zero" - Bruxelles, 19.6.2019 SWD(2019) 283 final

38. World Health Organization. Global status report on road safety 2015. http://www.who.int/violence_injury_prevention/road_traffic/en/

39. Jihong Zhou, Jun Qiu. Current Developments on Traffic Medicine. Advanced Trauma and Surgery, 2016: 59-77. 